\title{
Monumentality and the development of the Tongan maritime chiefdom
}

\author{
Geoffrey Clark ${ }^{1}$, David Burley ${ }^{2} \&$ Tim Murray $^{3}$
}

On Tongatapu the central place of the rising kingdom of Tonga developed in the fourteenth and fifteenth centuries $A D$. Marked out as a monumental area with a rock-cut water-carrying ditch, it soon developed as the site of a sequence of megalithic tombs, in parallel with the documented expansion of the maritime chiefdom. The results of investigations into these structures were achieved with minimum intervention and disturbance on the ground, since the place remains sacred and in use.

Keywords: Tonga, Neolithic, Megalithic, fifteenth century AD, chiefdom, kingdom, mortuary practice, princely burial

\section{Introduction}

The kingdom of Tonga incorporates 169 islands spread over a linear distance of $800 \mathrm{~km}$ along the western edge of the Polynesian triangle (Figure 1). Despite a total land area of only $700 \mathrm{~km}^{2}$, and an estimated late-prehistoric population of $30000-40000$ people (Green 1973; Burley 2007), Tonga became the centre for a complex maritime chiefdom during the second millennium AD (Aswani \& Graves 1989; Sand 1999; Petersen 2000; Neich 2006). Tongan hegemony and influence extended widely throughout the central Pacific, and the chiefdom's political integration is rivalled in complexity only by the Hawaiian chiefdom of the historic era (Kirch 1990).

Lapaha was the central place of the chiefdom during the height of its influence. It was critically positioned on the Fanga 'Uta lagoon on the southern island of Tongatapu (Sacred Tonga) (Figure 2). The chiefdom was headed by the paramount Tu'i Tonga (Lord of Tonga), who, along with other senior lineages, was buried in massive stone-faced tombs known as langi, meaning sky or heaven (Churchward 1959: 282). The tombs of the paramount chiefs, and other built structures at Lapaha, have long been recognised as central to tracing the development of the complex and highly stratified Polynesian society (Gifford 1929: 3-4; Kirch 1984; 1990; Spennemann 1989a \& b).

In this paper we present the first archaeological data for the large-scale prehistoric constructions at Lapaha, and use it to investigate the growth of the centralised and complex chiefdom. The monumental architecture sequence at Lapaha suggests an initial focus on social integration from an emphasis on maritime accessibility and the creation of a large

1 Archaeology and Natural History, Research School of Pacific and Asian Studies, Australian National University, Canberra, ACT 0200, Australia (Email: geoffrey.clark@anu.edu.au)

2 Department of Archaeology, Simon Fraser University, Burnaby, British Columbia V5A 1S6, Canada

School of Historical and European Studies, Martin Building, La Trobe University, Victoria 3086, Australia

Received: 13 February 2008; Accepted: 27 February 2008; Revised: 5 March 2008

ANTIQUITY 82 (2008): 994-1008 
Geoffrey Clark, David Burley \& Tim Murray

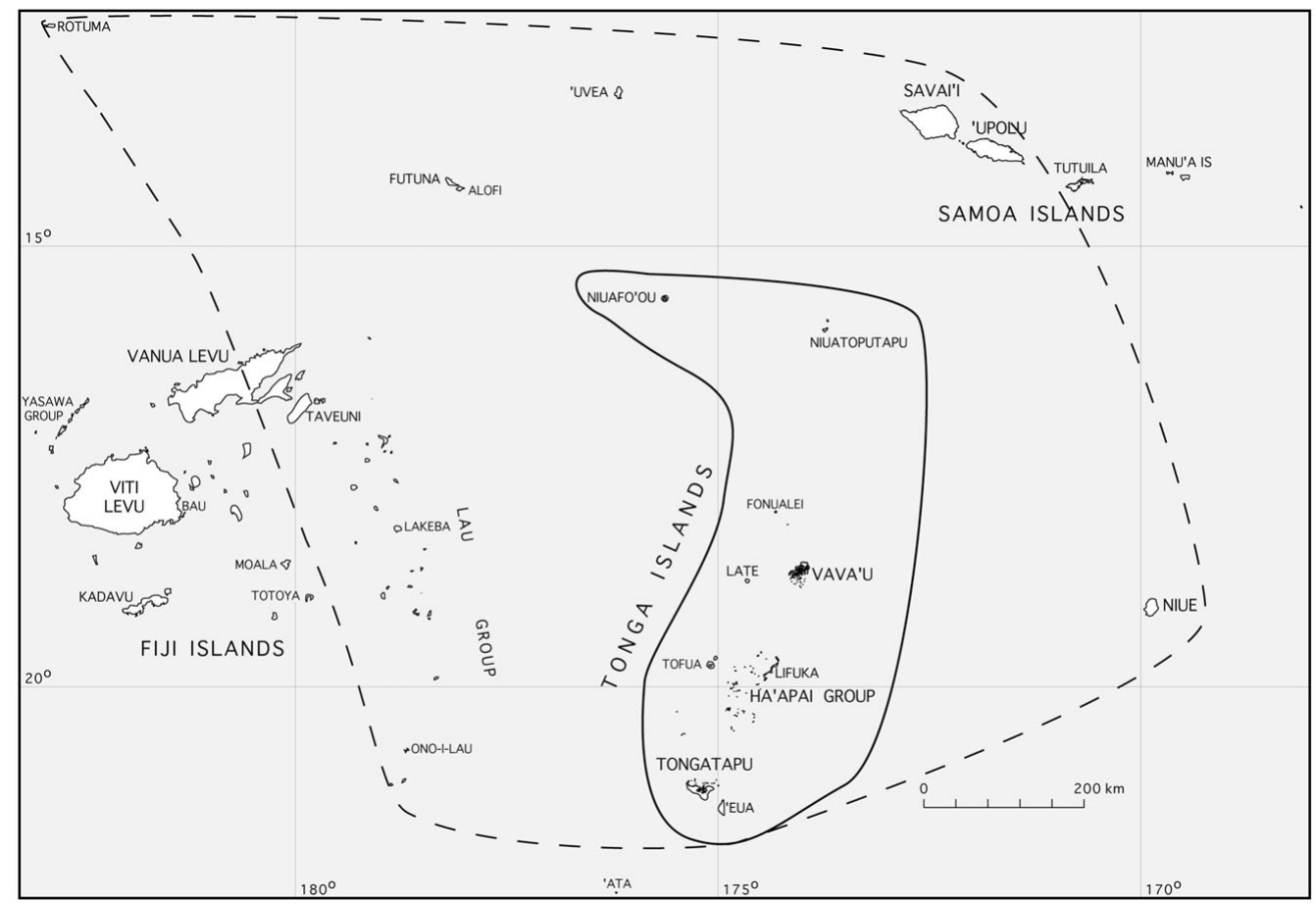

Figure 1. The kingdom of Tonga (black line) and main islands of the central Pacific influenced by the Tongan maritime chiefdom in traditional history (dashed line).

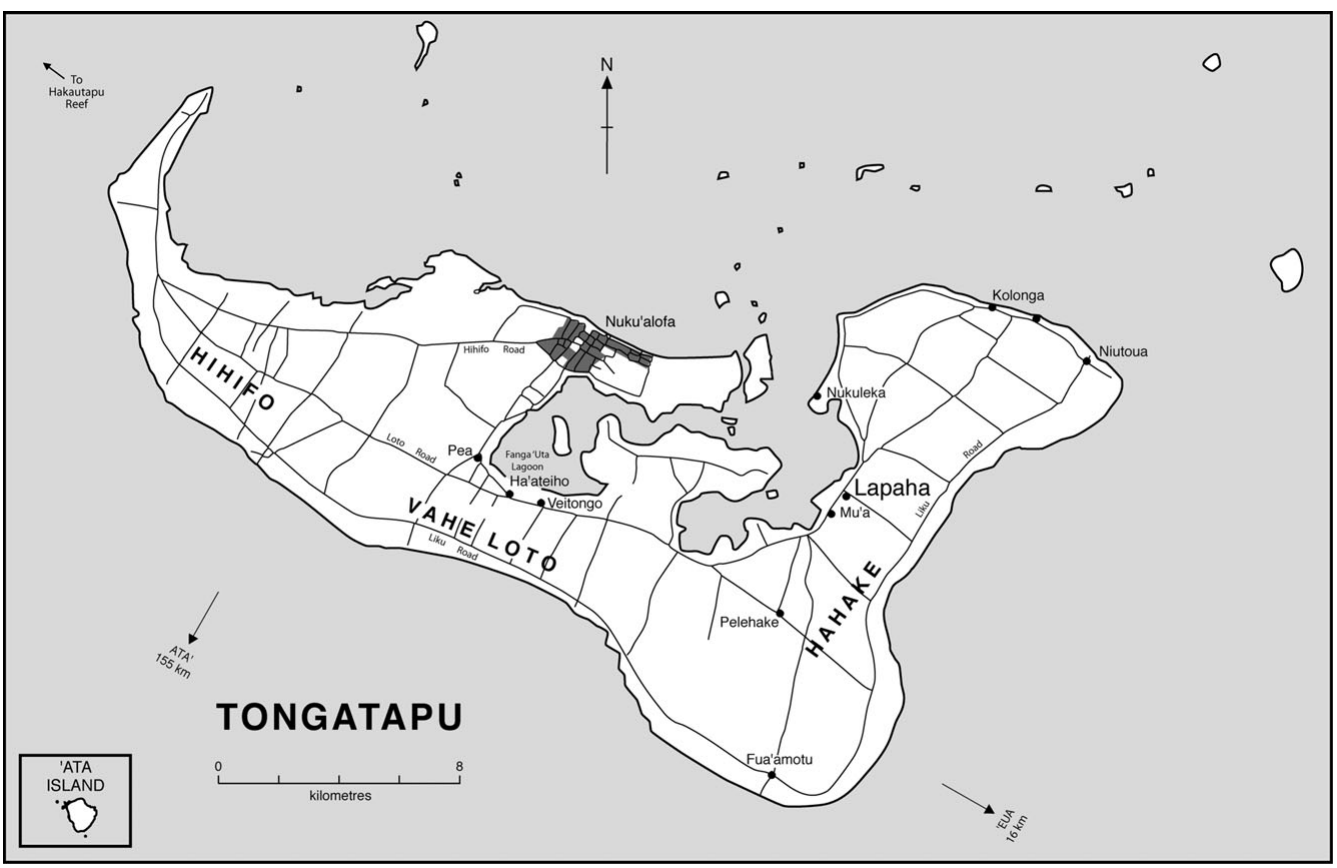

Figure 2. Tongatapu Island and location of Lapaha. 
ceremonial area outlined by a limestone-cut waterway. After AD 1450 there was a substantial increase in the sacredness of chiefs as manifested by the construction of large tiered burial structures. The sequence of monumental architecture suggests that chiefs utilised distinct leadership strategies during the development and expansion of the maritime chiefdom.

\section{Monumental structures}

The stone-faced tombs at Lapaha were first mapped in 1827 during Dumont d'Urville's visit to Tonga (Maurat 1833), with subsequent mapping and traditional information collected by missionaries, historians and archaeologists (Baker n.d.; Gifford 1929; McKern 1929; Bott 1982; Spennemann 1989a). As part of the Bishop Museum's Bayard-Dominick expedition to Tonga in 1920/21, McKern (1929) provided the first comprehensive map of the site as well as data for individual tombs and other features, the latter including an enclosing ditch bounded by a former shoreline.

In 2006 and 2007, the largest tombs were cleared of dense vegetation by Geoffrey Clark and a team from Lapaha village, and were mapped using laser scanning, optical theodolite and GPS. We also measured individual stones incorporated in the facing walls and, for the nine largest tombs, initiated a remote sensing project seeking the locations of burial vaults or interment pits. The clearing project and additional survey revealed 11 new structures as well as cases of landscape alteration that were previously missed. Our updated map of Lapaha and its features is shown in Figure 3. Here we continue to use and add to McKern's numbering system with the 'J' prefix in preference to traditional names for the tombs. Names differ between informants and historical sources leading to considerable confusion (Spennemann 1989a $\&$ b). Table 1 lists mounds and platforms on our map, provides traditional names as reported by McKern or contemporary Lapaha residents and gives an estimate of structure area. In addition to the tombs, the map identifies and repositions such features as shoreline and harbour topography, the canoe wharf, the fortification ditch and an area identified as reclaimed land.

\section{Tombs}

The seven largest tombs lie east of the old shoreline (J01, J03, J04, J09, J10, J15, J17) and to the immediate west of these tombs; clearly associated with them are 10 smaller stone-edged platforms (Figure 4). Three of the largest tombs (J01, J03, J04) lie within the arms of a ditch, now partly infilled, containing the domestic compound of the Tu'i Tonga (Olotele) and stone platforms of Loamanu, marking the burial place of the later collateral Tui Ha'atakalua lineage (McKern 1929; Bott 1982). East of the old shoreline, or on it, are several smaller groups of stone and earth structures (J18-J19 and J21-J25), including the two stone tombs of J20 and J21 to the east (Figure 3). A laser scan view in Figure 4 shows the position and relative height of the large tombs and old shoreline edge, as well as features such as trenches excavated to provide the fill for the two earth mound tombs of J04 and J01.

The tombs are still used as burial sites today and only small excavations were permitted on the outside of tomb walls to examine tomb construction and to recover samples of charcoal and marine shell for radiocarbon dating. The large tombs (J03, J09, J10 and J17) faced with beach rock slabs were consistently built by digging a trench with a sloping side that was 


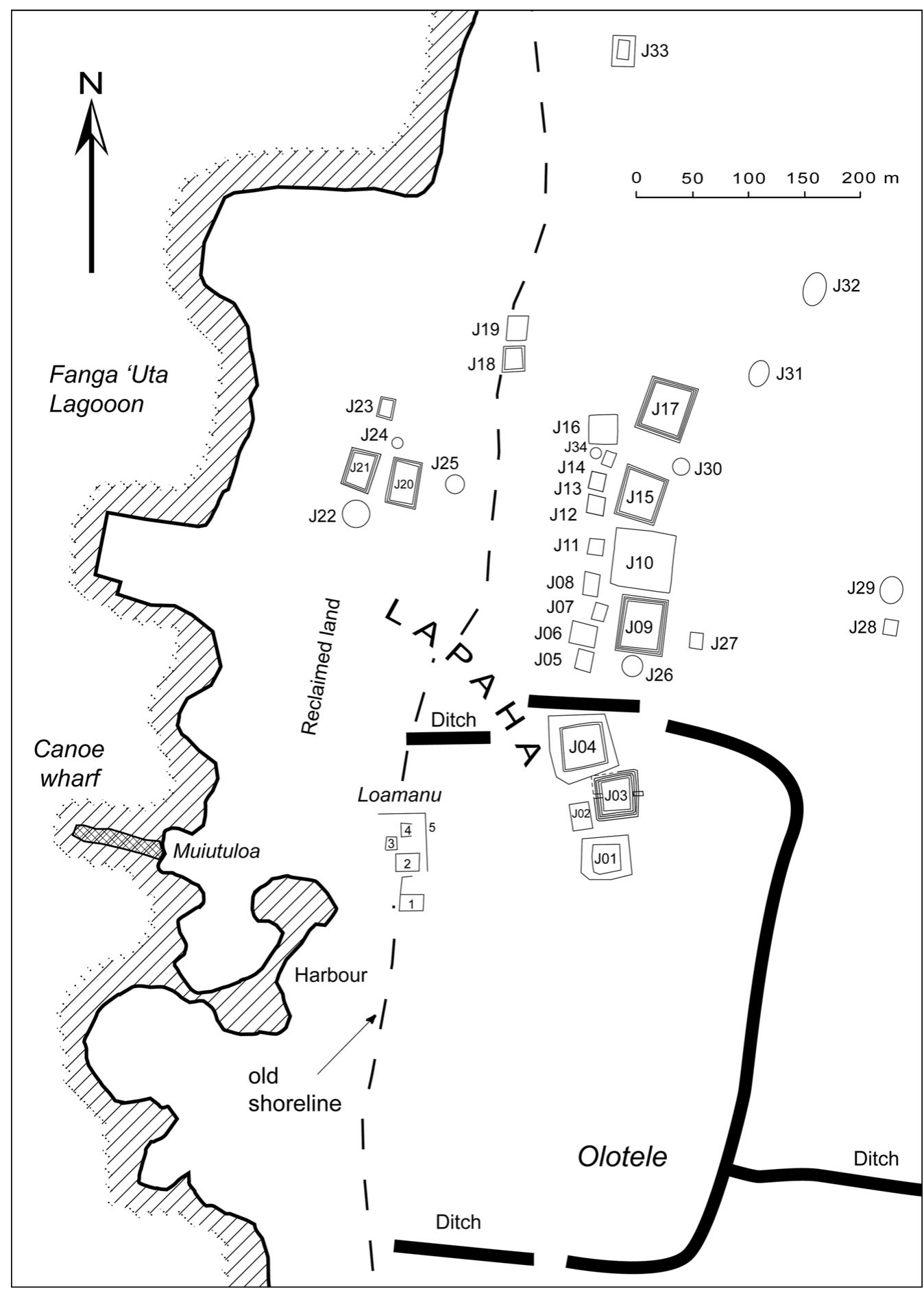

Figure 3. Plan view of the major built features at Lapaha, Tongatapu (See Tables 1 and 2). 
Table 1. Stone edged mounds and earth mounds recorded at Lapaha (excluding those in the Loamanu complex, McKern 1929: 95). See Figure 3 for structure location.

\begin{tabular}{|c|c|c|c|}
\hline Structure & Name(s) & Description & Area $\mathbf{m}^{2}$ \\
\hline J01 & Tuoteau & $\begin{array}{l}\text { Earth mound with single stone tier } \\
\text { on mound top }\end{array}$ & 651 \\
\hline J02 & Tau'atonga & Single stone tier & 444 \\
\hline $\mathrm{J} 03$ & Katoa & Five stone tiers & 1584 \\
\hline J04 & Tuofefafa, Fo'ou, Tofa'ua & $\begin{array}{l}\text { Earth mound with two stone tiers } \\
\text { on mound top }\end{array}$ & 1302 \\
\hline J05 & Sinai & Single stone tier & 265 \\
\hline J06 & Taetaea & Single stone tier & 580 \\
\hline J07 & Nukulau, Fa'apite & Single stone tier & 220 \\
\hline J08 & Tafaua, Puipui & Earth mound with single stone tier & 350 \\
\hline J09 & Leka, Lekamakatuituioha, Tau'atonga & Four stone tiers & 2128 \\
\hline $\mathrm{J} 10$ & Tauhala & Single stone tier & 2731 \\
\hline $\mathrm{J} 11$ & Ko'olonamu, Nukulau 1, Tamatiu & Two stone tiers & 261 \\
\hline $\mathrm{J} 12$ & $\begin{array}{l}\text { Tamatiu, Malua'otonga, Nukulau 2, } \\
\text { Koolonamu }\end{array}$ & Single stone tier & 255 \\
\hline J13 & Ma’u, Tofaua & Single stone tier & 174 \\
\hline $\mathrm{J} 14$ & Fo'ou & Single stone tier & 123 \\
\hline J15 & Fa'apite, Malua’otonga, Lili & Three stone tiers & 1572 \\
\hline J16 & Malua'otonga, Matuatonga, Tuituiohu & Single stone tier & 643 \\
\hline $\mathrm{J} 17$ & Leka, Puipui, Mau & Four stone tiers. & 1854 \\
\hline J18 & Nakulu ki Langi & Two stone tiers & 545 \\
\hline J19 & Langilangi Fehi & Single stone tier & 261 \\
\hline $\mathrm{J} 20$ & Paepae'otelea & $\begin{array}{l}\text { Three stone tiers; bottom two are } \\
\text { reef limestone and the top is } \\
\text { beach rock }\end{array}$ & 1166 \\
\hline $\mathrm{J} 21$ & Namoala, Tapa'iteau & Three stone tiers. Exposed vault lid & 864 \\
\hline $\mathrm{J} 22$ & Hehea & $\begin{array}{l}\text { Conical earth mound, two vaults } \\
\text { exposed on top }\end{array}$ & 280 \\
\hline $\mathrm{J} 23$ & Malomaloa’a, Olomaloa’a & Two stone tiers & 276 \\
\hline $\mathrm{J} 24$ & No name & Earth mound & 149 \\
\hline $\mathrm{J} 25$ & Esi ai Kona & Earth mound with coral boulder fill & 154 \\
\hline $\mathrm{J} 26$ & No name & Earth mound & 171 \\
\hline $\mathrm{J} 27$ & Kofe & Single stone tier & 208 \\
\hline $\mathrm{J} 28$ & Apolima (langi) & Single stone tier & 72 \\
\hline J29 & Apolima (cemetery) & Earth mound & 260 \\
\hline $\mathrm{J} 30$ & No name & Earth mound & 121 \\
\hline $\mathrm{J} 31$ & Heilala, Tui Amanave & Earth mound & 470 \\
\hline $\mathrm{J} 32$ & Taunga'eiki, Lili & Earth mound & 690 \\
\hline $\mathrm{J} 33$ & Faletoonga, Tuitonga & $\begin{array}{l}\text { Earth mound with single stone tier } \\
\text { on mound top }\end{array}$ & 340 \\
\hline $\mathrm{J} 34$ & No name & Earth mound & 70 \\
\hline
\end{tabular}

used to position stone slabs, before the alignment and height of slabs was adjusted in situ by wedging and dressing. Packing material, usually fragments of beach rock and coral, was placed in the foundation trench to hold the slabs in place, and in some tombs construction debris was used as a decorative perimeter border. 


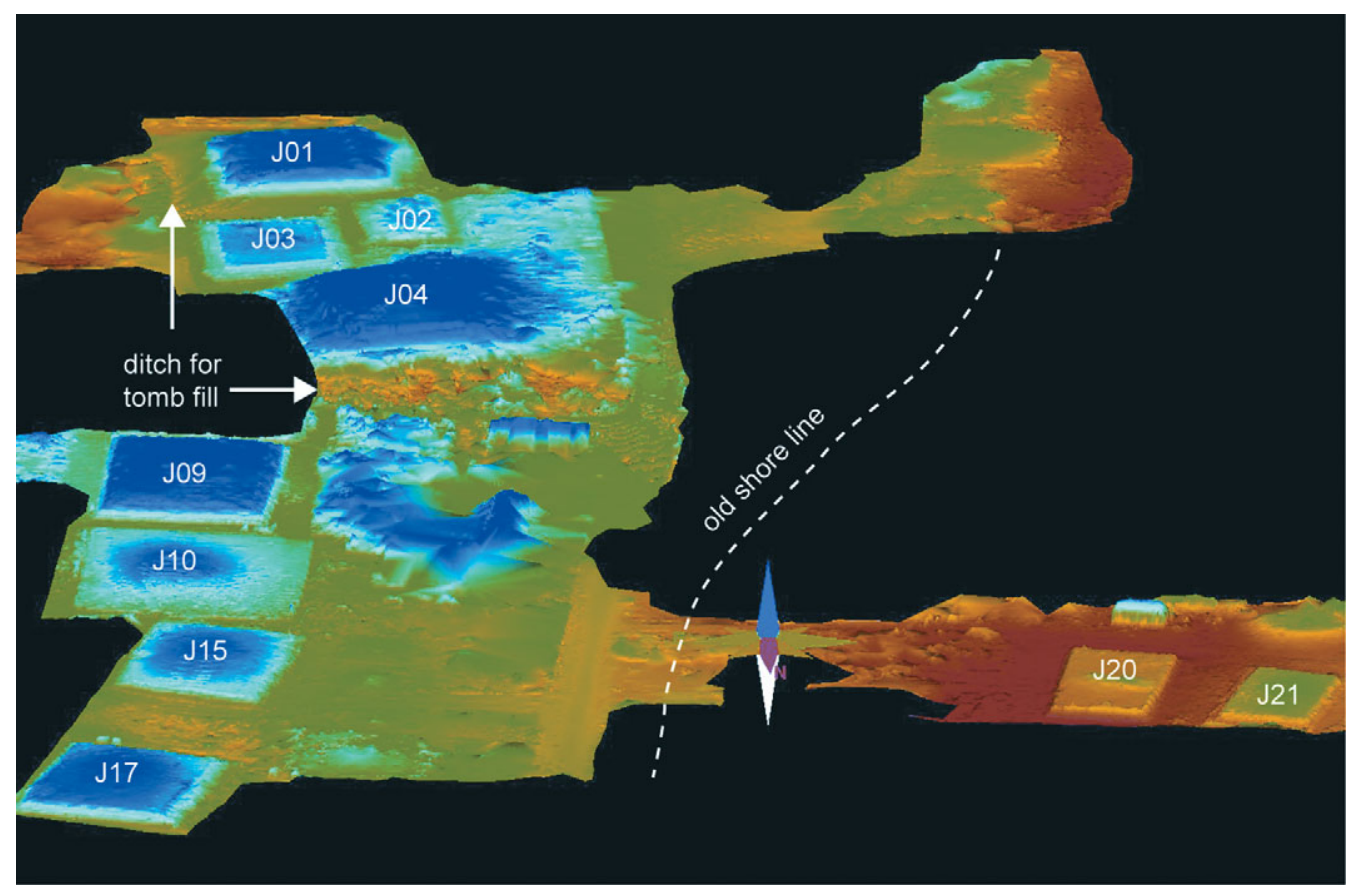

Figure 4. Laser scan image (south view) of the largest tombs at Lapaha coloured by elevation (red = low-lying land reclaimed from the lagoon).

The largest tombs share a rectangular to square plan, but otherwise differ markedly from one another in their area/volume, number of stone tiers, type of construction material and architectural features. These data are provided in Tables 1 and 2. The dominant type of stone employed in tomb construction is beach rock, a material found within the inter-tidal zone of most of Tonga's numerous coral-limestone islands. Beach rock occurs as a surface veneer of sand and other beach debris cemented together by calcium carbonate precipitate (Burley 1997). It is easily quarried, but the cut stones need to be transported by canoe for use in tomb construction. The largest beach rock slab was found in tomb J10. The slab is $9.9 \mathrm{~m}$ long and has an above ground height of $2.4 \mathrm{~m}$, with an estimated weight of 50 tons, similar to the largest stones in the Stonehenge trilithons.

Only tomb J20 differs in stone type, with its two bottom tiers constructed of massive blocks of quarried reef limestone. The average weight of the basal stones at J20 is 10 tons. The quality of stone dressing and fitting also varies among the tombs, with the larger tombs illustrating the highest degrees of craftsmanship. Select stone slabs on at least two of the tombs, J03 and J21, also have been decorated with geometric carved petroglyphs (McKern 1929: 79).

Increased variation among the large tombs is shown by a plot of fill volume versus stone weight for 21 large and small stone-faced structures (Figure 5). Four of the largest tombs lie outside the 95 per cent confidence interval of the regression line, suggesting that tomb builders chose to differentiate structures by increasing the amount of structure fill relative to the quantity of stone facing $(\mathrm{J} 01, \mathrm{~J} 04, \mathrm{~J} 10)$ or by contributing greater quantities of stone 
Table 2. Metric attributes for 21 structures made with beach rock and limestone slabs (see Figure 3 for structure location).

\begin{tabular}{lccccc}
\hline Structure & $\begin{array}{c}\text { Fill volume } \\
\left(\mathbf{m}^{\mathbf{3}}\right)\end{array}$ & $\begin{array}{c}\text { No. of } \\
\text { measured slabs }\end{array}$ & $\begin{array}{c}\text { Mean slab } \\
\text { length }(\mathbf{m})\end{array}$ & $\begin{array}{c}\text { Stone volume } \\
\left(\mathbf{m}^{\mathbf{3}}\right)\end{array}$ & $\begin{array}{c}\text { Estimated stone } \\
\text { weight (tons) }\end{array}$ \\
\hline J01 & 5985 & 70 & 1.6 & 16.5 & 44 \\
J02 & 161 & 48 & 1.3 & 5.8 & 16 \\
J03 & 1765 & 328 & 1.8 & 71.4 & 190 \\
J04 & 8265 & 109 & 2.5 & 85.6 & 228 \\
J05 & 64 & 24 & 0.7 & 1.5 & 4 \\
J06 & 297 & 46 & 1.5 & 8.1 & 21 \\
J07 & 58 & 27 & 1.2 & 2.2 & 6 \\
J08 & 206 & 59 & 1.2 & 8.3 & 22 \\
J09 & 6745 & 200 & 3.3 & 185.3 & 494 \\
J10 & 3865 & 69 & 3.0 & 77.7 & 197 \\
J11 & 95 & 24 & 1.4 & 5.6 & 11 \\
J12 & 75 & 55 & 1.0 & 2.7 & 7 \\
J13 & 44 & 39 & 1.0 & 1.6 & 4 \\
J15 & 3380 & 207 & 2.2 & 105.0 & 30 \\
J16 & 322 & 69 & 1.4 & 11.2 & 276 \\
J17 & 3870 & 298 & 2.2 & 103.8 & 519 \\
J20 & 3561 & 90 & 2.8 & 224.0 & 126 \\
J21 & 1310 & 174 & 2.0 & 47.0 & 4 \\
J23 & 146 & 79 & 1.2 & 5.6 & 3.0 \\
J27 & 52 & 54 & 0.9 & 2.2 & \\
J28 & 22 & 5 & 0.8 & 1.0 & \\
\hline
\end{tabular}

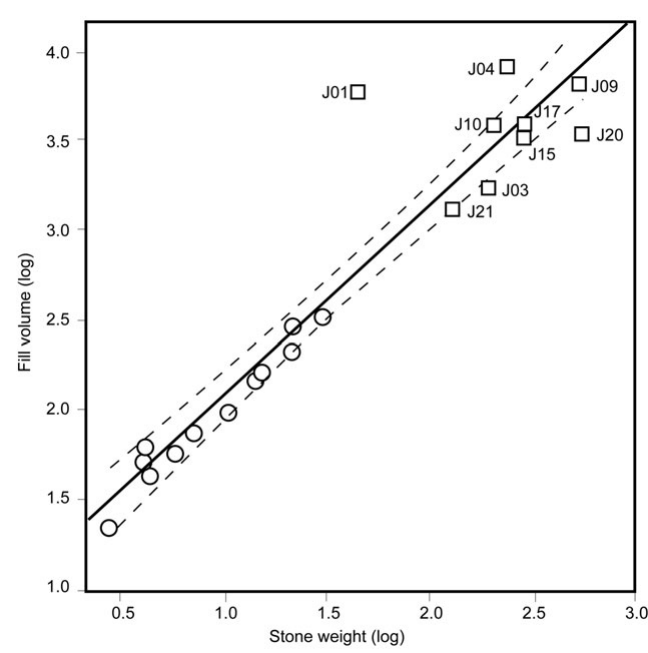

Figure 5. Logplot of volume versus stone weight for 21 stonefaced structures at Lapaha. Squares are the large tombs shown in Figures 2 and 3. Circles are the small platforms/tombs (J02, J03, J05-J08, J11-J13, J23, J27 and J28) in Figure 3. relative to tomb size/volume (J03 and J20). In contrast, fill volume and stone weight are highly correlated $(r=0.9)$ for all the smaller platforms, and for four of the large tombs which have either three or four stone tiers (J09, J15, J17 and J21). This suggests at least three general styles of tomb architecture: (1) tombs where the amount of stone facing is correlated with structure volume; (2) tombs where there is more stone in proportion to structure volume; (3) tombs where there is significantly less stone relative to structure volume.

Smaller oval or circular mounds of earth and sand are associated with the langi and tend to be located on either the north or the south side of the largest tombs. Often described as chiefs' sitting platforms (esi), at least some of these mounds were used for 
burial of individuals closely associated with the Tu'i Tonga. Stone vaults were recorded in two, J22 and J26, and human bone was found eroding from J25. Two earth mounds, J31 and J32, are identified in tradition as burial mounds of the Falefa, chiefs of the Tu'i Tonga's court.

\section{Land reclamation, harbour and canoe wharf}

The western ends of the enclosure ditch terminate at the old shoreline indicating that the coastal flat has expanded lagoon-ward after the ditch was cut. Oral traditions assert that the area was reclaimed from inter-tidal lagoon flats by an early Tu'i Tonga. McKern (1929: 100) dismissed this as improbable considering the scale of the project. Kirch (1984: 227) and Spennemann (1989a: 463), on the other hand, believed purposeful infilling had taken place. Excavations adjacent to the J20 and J21 tombs demonstrate that at least some areas

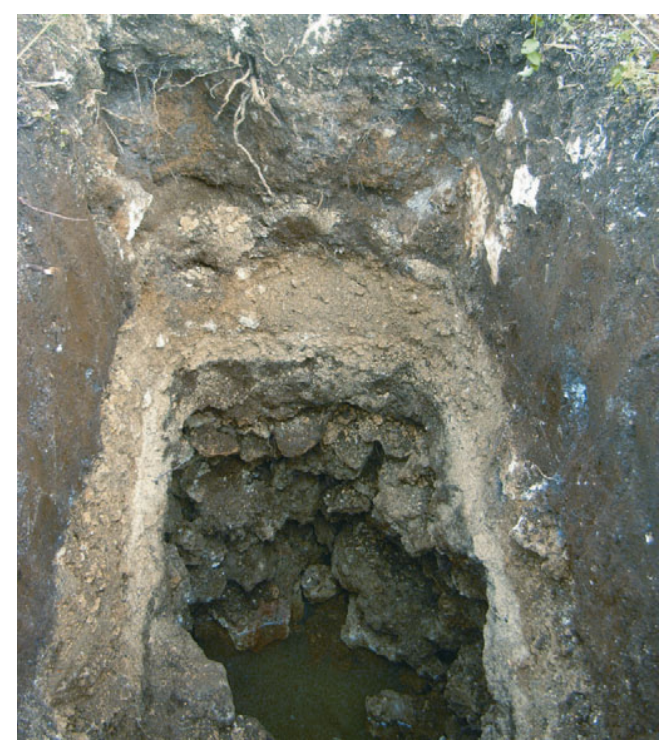

Figure 6. Section through reclaimed land near the J21 tomb. east of the old shoreline coast were reclaimed by depositing a layer of coral rubble above the tidal range, sealing the rubble with a thin deposit of soil, followed by layers of limestone and soil (Figure 6). The volume of the fill deposit in the vicinity of the excavated area is calculated from laser scan topography as $17000 \mathrm{~m}^{3}$, with the potential extent of prehistoric land reclamation requiring more than $100000 \mathrm{~m}^{3}$ of fill.

The reclaimed land to the south of the canoe wharf, Muiutuloa, holds a small harbour protected by a narrow entrance for mooring large double-hulled canoes. Now a mangrove swamp, at least some of the canoe harbour was faced with coral boulders and cut beach rock slabs that are now buried by mangrove mud (McKern 1929: 98). The canoe wharf is largely eroded and consists of a pile of large submerged coral blocks extending $80 \mathrm{~m}$ into the lagoon. The base of the wharf is preserved and excavation shows it was built on a base of coral boulders and fragments of worked beach rock. This layer was then covered with a thin layer of soil and a thicker deposit of beach sand.

\section{Enclosure ditch}

The ditch surrounding the compound of Olotele and extending eastward is a complicated feature generally $7-10 \mathrm{~m}$ wide and $2-4 \mathrm{~m}$ deep that exceeds $3 \mathrm{~km}$ in total length. It is now built over in several places by roads and house foundations. The enclosure ditch is clearly older than the J04 tomb, as soil from a shallow but wide excavation north of J04 (Figure 3) provided the $8000 \mathrm{~m}^{3}$ of tomb fill that appears to have buried the ditch. The ditch has previously been considered a defensive earthwork built to protect the compound of the Tu'i 


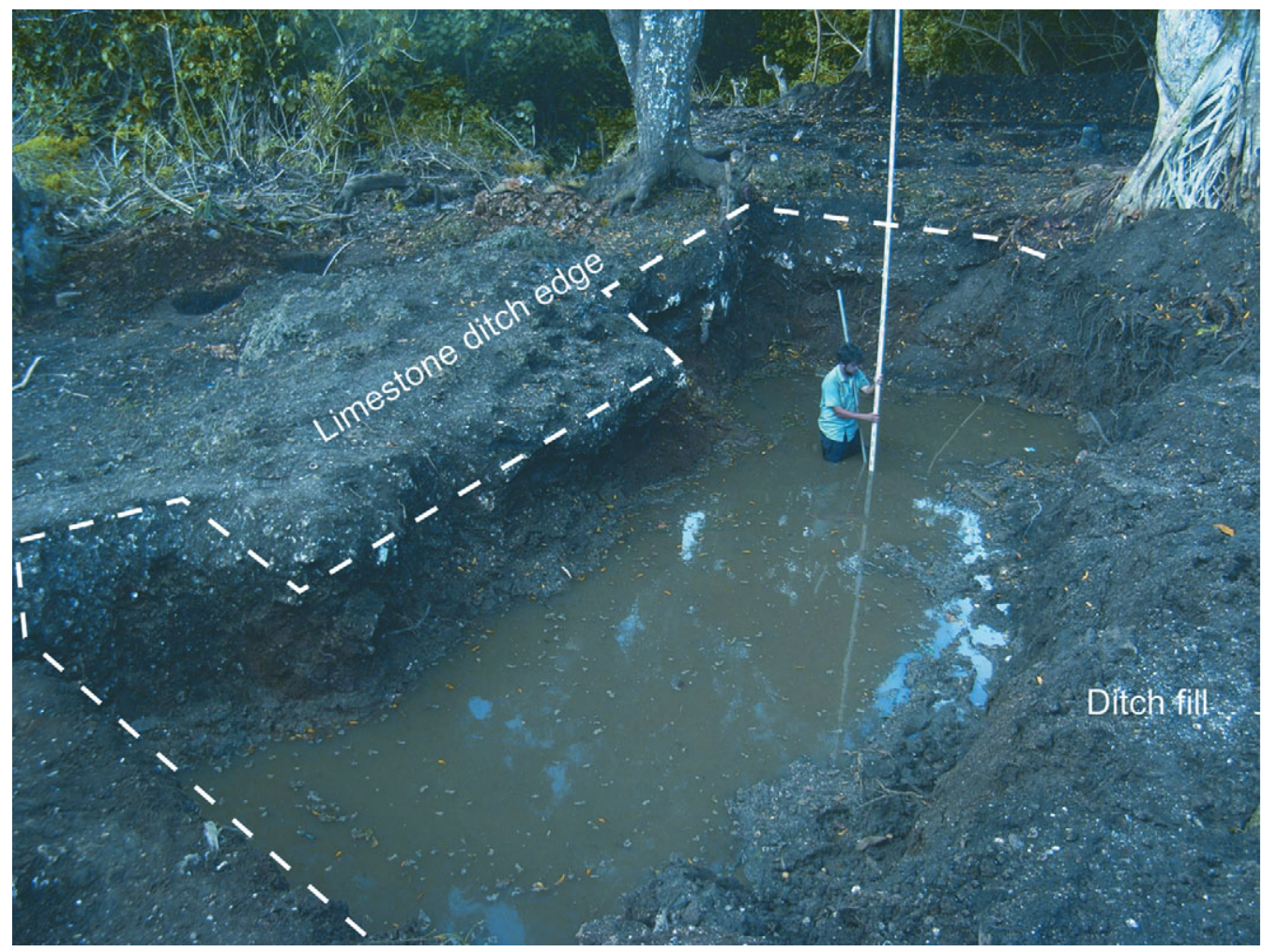

Figure 7. The ditch-waterway cut in to the limestone bedrock (north-west end).

Tonga (McKern 1929: 93; Spennemann 1989b: 190) and is similar in form to earthwork fortification ditches made during the civil wars of the nineteenth century.

Excavation of a north-west section of the ditch (Figure 7) showed, however, that it is not an earthwork construction, and was made by quarrying the limestone bedrock to tap the freshwater aquifer $2-3 \mathrm{~m}$ below the ground surface. The ditch is a unique structure in Oceania, and an estimated 28000 tons of limestone was quarried in its construction. Tongatapu has no fresh water lakes, rivers or streams and the creation of an artificial waterway is a highly symbolic transformation of the landscape by the Tu'i Tonga. Extensive clearance of the ditch sides did not reveal any postholes in the limestone necessary for a defensive wall or palisade (cf. McKern 1929: 93). A water-holding function of the ditch-waterway is also suggested by the termination of the northern arm of the ditch in shoreline limestone, and is in accord with Lapaha oral traditions that have the ditch as a water-filled boundary marking the ceremonial chiefly precinct, which has an area of $c .140000 \mathrm{~m}^{2}$.

\section{Radiocarbon dates and a chronology for Lapaha}

To establish a chronology for tomb and other features constructed at Lapaha, samples of charcoal and marine shell were collected for radiocarbon dating from excavations at the base of several tombs (J03, J04, J10, J21), from reclaimed land near J21, from the canoe wharf, 
Table 3. Radiocarbon results from Lapaha. See Figure 3 for the location of prehistoric structures. All charcoal samples were dated by AMS.

\begin{tabular}{|c|c|c|c|c|c|c|}
\hline Structure & $\begin{array}{l}\text { Context and } \\
\text { depth }(\mathrm{cm})\end{array}$ & Material & Lab. No. & ${ }^{13} \mathrm{C}$ & CRA & Cal AD \\
\hline \multirow[t]{3}{*}{ Reclamation } & TP.3:85 & Charcoal & Wk-21816 & $-26.2 \pm 0.2$ & $560 \pm 35$ & $1310-1430$ \\
\hline & TP.1:180 & Charcoal & Wk-21813 & $-25.8 \pm 0.2$ & $589 \pm 35$ & $1320-1440$ \\
\hline & TP.3: 146 & Anadara sp. & Wk-21814 & $1.1 \pm 0.2$ & $974 \pm 35$ & $1320-1440$ \\
\hline \multirow[t]{2}{*}{ Ditch infill } & Depth:276 & Periglypta crispate & Wk-21822 & $1.9 \pm 0.2$ & $828 \pm 35$ & $1430-1540$ \\
\hline & Depth:276 & Charcoal & Wk-21821 & $-26.8 \pm 0.2$ & $320 \pm 35$ & $1480-1650$ \\
\hline \multirow[t]{2}{*}{ Canoe wharf } & ТP.1:78 & Charcoal & Wk-21819 & $-27.6 \pm 0.2$ & $357 \pm 35$ & $1450-1640$ \\
\hline & TP.1:136 & Charcoal & Wk-21820 & $-28.0 \pm 0.2$ & $286 \pm 35$ & $1490-1670$ \\
\hline \multicolumn{7}{|l|}{ Tombs } \\
\hline J02 & TP.3: 35 & Anadara sp. & Wk-20125 & $1.7 \pm 0.2$ & $688 \pm 30 \mathrm{BP}$ & $1530-1680$ \\
\hline $\mathrm{J} 02$ & TP.3: 45 & Anadara sp. & Wk-20122 & $1.6 \pm 0.2$ & $679 \pm 41 \mathrm{BP}$ & $1520-1690$ \\
\hline J03 & TP.1: 52 & Charcoal & Wk-18786 & $-26.7 \pm 0.2$ & $380 \pm 29 \mathrm{BP}$ & $1450-1630$ \\
\hline J03 & TP.1: 57 & Anadara sp. & Wk-18770 & $1.1 \pm 0.2$ & $825 \pm 32 \mathrm{BP}$ & $1430-1550$ \\
\hline J03 & TP.2: 105 & Charcoal & Wk-20123 & $-28.1 \pm 0.2$ & $481 \pm 41 \mathrm{BP}$ & $1390-1480$ \\
\hline $\mathrm{J} 03$ & TP.2: 137 & Charcoal & Wk-20124 & $-26.6 \pm 0.2$ & $449 \pm 41 \mathrm{BP}$ & $1410-1620$ \\
\hline J04 & Layer 4 & Charcoal & Wk-21825 & $-22.5 \pm 0.2$ & $175 \pm 30 \mathrm{BP}$ & $1660-1950$ \\
\hline J04 & Layer 7 & Charcoal & Wk-21823 & $-26.2 \pm 0.2$ & $378 \pm 30 \mathrm{BP}$ & $1450-1630$ \\
\hline J09 & TP.1: 35 & Charcoal & Wk-18783 & $-27.7 \pm 0.2$ & $798 \pm 29 \mathrm{BP}$ & $1205-1276$ \\
\hline J09 & TP.1: 35 & Charcoal & Wk-18784 & $-27.3 \pm 0.2$ & $839 \pm 29 \mathrm{BP}$ & $1160-1270$ \\
\hline J09 & TP.1: 38 & Charcoal & Wk-18775 & $-27.9 \pm 0.2$ & $829 \pm 29 \mathrm{BP}$ & $1160-1285$ \\
\hline J09 & TP.1: 48 & Charcoal & Wk-18774 & $-27.8 \pm 0.2$ & $777 \pm 30 \mathrm{BP}$ & $1220-1260$ \\
\hline J09 & TP.2: 95 & Charcoal & Wk-20126 & $-26.0 \pm 0.2$ & $400 \pm 41 \mathrm{BP}$ & $1430-1630$ \\
\hline $\mathrm{J} 10$ & TP.1: 40 & Anadara sp. & Wk-18772 & $1.7 \pm 0.2$ & $690 \pm 31 \mathrm{BP}$ & $1530-1680$ \\
\hline $\mathrm{J} 10$ & TP.1: 40 & Charcoal & Wk-18773 & $-24.2 \pm 0.2$ & $347 \pm 29 \mathrm{BP}$ & $1460-1640$ \\
\hline $\mathrm{J} 10$ & TP.1: 55 & Charcoal & Wk-18777 & $-24.1 \pm 0.2$ & $411 \pm 28 \mathrm{BP}$ & $1430-1620$ \\
\hline $\mathrm{J} 10$ & TP.1: 88 & Charcoal & Wk-18776 & $-24.7 \pm 0.2$ & $654 \pm 28 \mathrm{BP}$ & $1280-1390$ \\
\hline $\mathrm{J} 21$ & TP.3:85 & Anadara sp. & Wk-21815 & $1.8 \pm 0.2$ & $681 \pm 35 \mathrm{BP}$ & $1530-1690$ \\
\hline
\end{tabular}

and from a section of the ditch. A total of 25 samples have been dated using radiometric and AMS methods at the University of Waikato Radiocarbon Dating Laboratory and Rafter Radiocarbon Laboratory in New Zealand. Table 3 provides the sample data, corrected radiocarbon and calibrated ages. Samples were dated only if clear association could be made with the construction event and associated deposits had no indication of later disturbance. Standard chemical pre-treatment $(\mathrm{ABA}), \mathrm{CO}_{2}$ production and graphitisation of charcoal were made at the Waikato dating facility, with graphite analysed at the Rafter laboratory. Dated charcoal was not identified to species. Marine shells were acid-etched with dilute $\mathrm{HCl}$ and tested for recrystallisation before dating. All determinations were calibrated at two standard deviations using the terrestrial and marine curves (IntCal04 and Marine04) of Calib Rev. 5.0.1 (Stuiver \& Reimer 1993).

Of the shell samples, several were Anadara sp. valves with heavily worked ventral margins. These we believe are discarded tools and relate directly to tomb construction. Samples of unmodified Anadara shell also were collected as associated midden debris deposited on 
coarse calcareous sand created by the moving and working of beach rock slabs. These shells might alternatively relate to post-construction activities and be slightly more recent. For correction of the ocean reservoir effect on shell dates, Spennemann and Head (1998: 104950) calculate a lagoon-specific DeltaR value of $87 \pm 74$ years for Tongatapu. This value is a result of limited water circulation and the presence of depleted ${ }^{14} \mathrm{C}$ from limestone bedrock. While an exact DeltaR figure does not exist for Lapaha per se, preliminary research by the Waikato Radiocarbon Laboratory suggests a relatively low value may be applicable, as do several shell-charcoal results listed in Table 3 . We consequently have set DeltaR at 0 for the samples reported here.

\section{Development of the chiefly centre}

The radiocarbon results (Table 3) and relative dating of prehistoric structures allow new insight to the architectural development of the Tongan chiefdom. Particularly important is the temporal relationship between the large monumental tombs associated with the Tu'i Tonga lineage and the establishment of the chiefly precinct, outlined by what appears to be a symbolic limestone-cut waterway and the reclamation of land.

\section{Chronology of the enclosure ditch, land reclamation and canoe wharf}

The enclosure ditch-waterway appears to have been built early, as it finishes at the old shoreline, indicating that land was reclaimed after the ditch was cut (Kirch 1984). As three radiocarbon dates indicate reclamation of the lagoon was underway by AD 1310-1440 (Wk21816, Wk-21813, Wk-21814), the ditch may have been built in the late thirteenth or early fourteenth century AD. Two ${ }^{14} \mathrm{C}$ determinations on samples from basal ditch sediments indicate infilling of the enclosure by $\mathrm{AD} 1500-1550$ (Wk-21822, Wk-21821). The range is supported by a charcoal result with an age of AD 1450-1630 (Wk-21823) from the base of the J04 tomb which was built over the ditch. The second result from J04 (Wk-21825, $175 \pm 30 \mathrm{BP}$ ) dates a thin charcoal layer above the mound base, representing vegetation clearance from later use of the burial mound. Two age results from the canoe wharf have a pooled age of AD 1490-1640, consistent with construction of the wharf after AD 1450.

\section{Tomb chronology}

Previous attempts have been made by McKern (1929), Gifford (1929), Kirch (1984) and Spennemann (1989a \& b) to provide an approximate construction sequence for Lapaha tombs based on traditional history, genealogical data or construction features. In several cases their results conflict, and none has been verified by absolute dates. Here we provide radiocarbon dates for five of the tombs. It is intriguing that Tongan traditions in several instances differ significantly on the issue of tomb name and age, as well as to who built the tombs and who was buried in them. This might be the result of a complex sequence of tomb use and re-use combined with the deliberate or inadvertent hiding of tomb history.

Of the dated tombs, possibly the oldest is J09. Four results, probably from the same piece of charcoal, provide a bracketing date of AD 1210-1260 (Wk-18783, Wk-18784, Wk-18775, Wk-18775). If accurate, this date coincides with the founding of the site by 
the twelfth Tu'i Tonga. To test the early date, a second excavation was made and a second charcoal sample was submitted for dating. This provides a contradictory age of AD 14301630 (Wk-18776). At this stage we suggest the age of J09 cannot definitively be established from the radiocarbon results. Traditional history related to the tomb is similarly confused (Gifford 1923; 1929: 53; McKern 1929: 41).

Three tombs inside the ditch enclosure, J02, J03 and J04, all post-date the ditch. The oldest, J03, is a five-tiered structure with a pooled age on three charcoal results of AD 1440-1490 (Wk-18786, Wk-20123, Wk-20124). J04, as given above, dates between AD 1450-1630 (Wk-21823) while J02 has a pooled age on marine shell of AD 1540-1680 (Wk-20125, Wk-20122). Excavations were not undertaken at J01, the other large tomb inside the enclosure. However, this tomb is associated with the thirty-sixth Tu'i Tonga, an individual who was alive during the visit of Captain Cook in 1777 (Bott 1982; Campbell 1992).

The only other large tombs for which radiocarbon dates are available at present are $\mathrm{J} 10$ and J21. Three measurements (Wk-18772, Wk-18773, Wk-18777) from J10 suggest construction after AD 1450-1500. An older date of AD 1280-1390 (Wk-18776) is an outlier and probably based on old wood. The single date from J21 provides an estimate of AD 1530-1690 (Wk-21815) for construction.

Although additional radiocarbon dating of structures is required, it is apparent that the area outlined by the ceremonial ditch-waterway did not contain any large tombs until after $c$. AD 1450, when most of the larger tombs and the canoe wharf were built. The harbour and reclaimed land east of the old shoreline are older and probably date to AD 1310-1420, when the ditch-waterway was also likely to have been made.

\section{Discussion}

Monumentality at Lapaha initially involved the establishment of an area outlined by a waterfilled boundary and the creation of new terrain, after which monumentality shifted to the construction of large, elevated chiefly tombs. The change from non-sepulchral architecture to large burial platforms for chiefs indicates a significant transformation in the authority and power of paramount chiefs after AD 1450.

In Tongan tradition, the change in architecture coincides closely with a critical point in the development of the chiefdom under the twenty-fourth Tu'i Tonga, Kau'ulufonua I. This chief was renowned for his political integration of the chiefdom and then its reorganisation into sacred Tu'i Tonga (senior) and secular Tu'i Ha'atakalaua (junior) paramountships. The spatial organisation of Lapaha was also reordered at that time so that lower (reclaimed) and upper divisions of land and followers could be associated with the Tu'i Ha'atakalaua and Tu'i Tonga respectively. This division, identified in Tongan as Kauhalalalo and Kauhala'uta, continues today as an important division for chiefly title and protocols (Bott 1982: 80-1).

Although there is still much to learn about the development of the central place a provisional interpretation must consider the function of the early limestone-cut enclosure and its association with reclaimed land and canoe harbour. All of these were built before $\mathrm{AD}$ 1450, with the harbour and sheltered lagoon location pointing to the importance of maritime transport for the newly delineated central place. 
Canoe access was particularly important for the inter-island 'first fruits' or inasi observance, held when the yam harvest neared maturity in October ('inasi: to share or apportion) (Gifford 1929: 76). The inasi was in part a religious act performed to ensure the favour of the gods, but in bringing chiefs and tribute from the outer islands to Lapaha it also manifested the political and economic integration of the chiefdom under the Tu' $i$ Tonga paramount. The inasi evidently predates AD 1450 (Gifford 1924: 49), and the creation of an area at Lapaha suitable for large-scale ceremony bounded by a water-filled ditch suggests that leaders may have been using the inasi and other ceremonies to promote social cohesion among local and non-local groups in the newly constituted and geographically dispersed chiefdom.

Social space at Lapaha was reorganised after AD 1450, and involved the infilling of the ditch and the construction of chiefly tombs inside the former enclosure. The marked elevation in chiefly influence after AD 1450 can be seen in the tombs themselves becoming a focus of the inasi ceremony (Gifford 1929: 76; Beaglehole 1967: 145-9; Martin 1991: 344).

The onset of large tomb construction around AD 1450 can be correlated with the imposition of a new chiefly structure by the twenty-fourth Tu'i Tonga, Kau'ulufonua I, which is dated genealogically to AD 1470 (Gifford 1929: 56). There is close agreement between the traditions regarding the timing and significance of Kau'ulufonua I and the archaeological dating of the large tombs. However, traditions about the Tu'i Tonga at Lapaha prior to Kau'ulufonua I are sparse, with the result that the nature and extent of the chiefdom before AD 1450 is poorly understood. For example, written and oral traditions do not mention that the ditch-waterway was dug through limestone bedrock despite the fact that its construction involved the removal of more than 10 times the total amount of stone used in the chiefly tombs.

Similarly, Tongan traditions only briefly refer to large-scale land reclamation and harbour construction. These projects also needed a sizeable labour force and planning under a central, and presumably predominantly secular, authority, although further research on this issue is clearly needed. That power and authority in Tonga operated differently after AD 1450 than before is nonetheless shown by a sharp rise in the sacred status of chiefs as seen in the size and complexity of their tombs.

The move toward chiefly sacredness and tomb building occurred at the peak of the Tu'i Tonga's influence under Kau'ulufonua I, who traditions associate with an aggressive phase of maritime activity in Tonga and islands such as Samoa, Futuna and 'Uvea (Gifford 1929: 55). By emphasising their semi-divine status chiefs were able to increase the social complexity of the chiefdom by further stratifying the political hierarchy and expanding the reach of the maritime society after $\mathrm{AD} 1450$. The potential benefits of such a strategy include long-term lineage dominance through generational succession and control over a dispersed population which owed obedience to the gods and their intermediaries - the semi-divine chiefs. The increasing sacredness of chiefs carries with it the risk, however, that leaders might become increasingly distanced from practical government and control. The dilution of power through collateral lineage segmentation is well attested in the Tongan maritime chiefdom, and by the mid-nineteenth century it had all but collapsed as a result of chiefly rivalry, warfare and the impact of European arrival, particularly the spread of Christianity (Bott 1982; Campbell 1992; Martin 1991). 


\section{Conclusion}

An archaeological study of Lapaha is essential for any historical or theoretical understanding of the Tongan maritime chiefdom and acts as an exemplar for the development of polities in the Pacific. Mapping, survey and test excavation projects demonstrate the complex nature of Lapaha's landscape, including chiefly burial tombs, an enclosure ditch-waterway, infilled and reclaimed land, a harbour and wharf construction.

Despite a relatively small population and Neolithic technology, the scale and density of monumental works at the chiefly centre of Lapaha is unprecedented in Polynesia, with more than 2500 tons of quarried stone used in the tombs alone. Large-scale monumentality was also a feature of the early Tongan chiefdom that has been underestimated because it is not recorded in traditions, and the infilled ditch and scale of reclamation are archaeologically less visible than the spectacular raised tombs built after AD 1450. The dramatic shift in the type and visibility of monumental structures at Lapaha indicates that chiefs initially transformed the landscape to create a central place for integrative activity, before constructing the highly visible tombs, which in contrast emphasised their sacred and remote status. How the changes to chiefly power and authority at the central place of Lapaha shaped relations on the periphery is now an important issue for understanding Tongan maritime expansion.

\section{Acknowledgements}

We gratefully acknowledge the active support and kind hospitality of the Lapaha community, particularly the Princess Siuilikutapu and the Honourable Kalanivalu. The Honourable Albert Tuivanuavou Vaea of the Tonga Traditions Committee facilitated the research and provided valuable advice and assistance. A grant from the Australian Research Council supported the fieldwork and analyses. We thank Titako Sili and Sitani Kautai for managing the Lapaha fieldwork crew, and Makalangahiva, head of the Lapaha ha'atufunga, Nivaleti Melekiola (town officer) and Pila Mateni for discussing the traditional history of the Tu'i Tonga with us. We thank students from the University of Otago (Rhonda Steel, Christopher Jennings) and the Australian National University (Laticia Wedhorn, Tom Sapienza, Emily Cobbold) for assisting in the field. We are also grateful to Dr Fiona Petchey (Waikato University) for advice on the calibration of marine shell dates, Jofe Jenkins for laser scan surveying and Antoine de Biran for geophysical research. We thank participants to the Tongan Maritime Chiefdom Workshop held at the ANU in November 2007 for their valuable comments, particularly Prince Tupouto'a Lavaka, Dirk Spennemann (Charles Sturt University) and Christophe Sand (Département d'archéologie, New Caledonia).

\section{References}

AsaWani, S. \& M.W. Graves. 1998. The Tongan maritime expansion: a case in the evolutionary ecology of social complexity. Asian Perspectives 37: 135-64.

BAKER, S.W. n.d. Koe gaahi lagi oku tu'u 'i Mu’a [Tombs in Mu'a where the Royal Family are buried]. Pacific Manuscripts Bureau 1203 Baker Papers Microfilm Reel List SB/214/2.

BeAgLeHole, J.C. (ed.) 1967. The journals of Captain James Cook on his voyages of discovery edited from the original manuscript. The voyage of the Resolution and Discovery 1776-1780 (Part One, Volume III). Cambridge: Cambridge University Press for the Hakuluyt Society.
BотT, E. 1982. Tongan society at the time of Captain Cook's visits: discussions with Her Majesty Queen Salote Tupou (Polynesian Society Memoir 44). Wellington: Polynesian Society.

BurLeY, D.V. 1998. Monumental architecture and the use of stone in the classical Tongan chiefdom, in C.M. Stevenson, G. Lee \& F. Morin (ed.) Easter Island in Pacific context. South Seas Symposium: Proceedings of the $4^{\text {th }}$ International Conference on Easter Island and East Polynesia, University of New Mexico, Albuquerque, 5-10 August 1997 (Easter Island Foundation Occasional Paper 4): 318-24. Woodland (CA): Easter Island Foundation. 
- 2007. Archaeological demography and population growth in the Kingdom of Tonga $950 \mathrm{BC}$ to the Historic Era, in P.V. Kirch \& J-L. Rallu (ed.) The growth and collapse of Pacific Island societies: archaeological and demographic perspectives: 177-202. Honolulu: University of Hawai'i Press.

Campbell, I. 1992. Island kingdom, Tonga ancient and modern. Christchurch: Canterbury University Press.

Churchward, C.M. 1959. Tongan Dictionary. London: Oxford University Press.

GIFFORD, E.W. 1923. Tongan place names (Bernice P. Bishop Museum Bulletin 6). Honolulu: Bishop Museum.

- 1924. Tongan myths and tales (Bernice P. Bishop Museum Bulletin 8). Honolulu: Bishop Museum.

- 1929. Tongan society (Bernice P. Bishop Museum Bulletin 60). Honolulu: Bishop Museum.

GreEN, R.C. 1973. Tonga's prehistoric population. Pacific Viewpoint 14: 61-74.

KIRCH, P.V. 1984. The evolution of Polynesian chiefdoms. Cambridge: Cambridge University Press.

- 1990. Monumental architecture and power in Polynesian chiefdoms: a comparison of Tonga and Hawaii. World Archaeology 22: 206-22.

MCKern, W.C. 1929. Archaeology of Tonga (Bernice P. Bishop Museum Bulletin 60). Honolulu: Bishop Museum.

MarTin, J. 1991. Tonga Islands: William Mariner's account (5th edition). Nukua'lofa, Tonga: Vava'u Press.
Maurat, L. 1833. Plan des tombeaux des chefs de Tongatabou. Plate No. 101, in Voyage de découvertes de l'Astrolabe exécuté par ordre du Roi, pendant les années 1826-1827-1829, sous le commandement de M. J. Dumont d'Urville. Volume 1: atlas historique. Paris: Tastu.

NeICH, R. 2006. Pacific voyaging after the exploration period, in K.R. Howe (ed.) Vaka Moana, voyages of the ancestors: the discovery and settlement of the Pacific: 198-245. Auckland: David Bateman.

Petersen, G. 2000. Indigenous island empires: Yap and Tonga considered. Journal of Pacific History 35: 5-27.

SAND, C. 1999. Empires maritimes préhistoriques dans le Pacifique: Ga'asialili et la mise en place d'une colonie tongienne a Uvea (Wallis, Polynésie occidentale). Journal de la Société des Océanistes 108 : 103-23.

Spennemann, D.H.R. 1989a. 'Ata ‘a Tonga mo ‘ata 'o Tonga: early and later prehistory of the Tongan Islands. A study in settlement and subsistence patterns, with special emphasis on Tongatapu. Volume I. Unpublished PhD dissertation, Australian National University.

- 1989b. 'Ata 'a Tonga mo 'ata 'o Tonga: early and later prehistory of the Tongan Islands. Volume I. 2 Appendices. Unpublished PhD dissertation, Australian National University.

Spennemann, D.H.R. \& M.J. Head. 1998. Tongan pottery chronology, ${ }^{14} \mathrm{C}$ dates and the hardwater effect. Quaternary Geochronology 17: 1047-56.

Stuiver, M. \& P.J. Reimer. 1993. Extended ${ }^{14} \mathrm{C}$ database and revised CALIB 3.0 ${ }^{14} \mathrm{C}$ calibration program. Radiocarbon 350: 215-30. 